\title{
Diseminasi Literacycloud untuk Guru dan Orangtua Sekolah Dasar Negeri Kecamatan Patumbak Deli Serdang dalam Masa Pandemi Covid-19
}

\author{
Kisno $^{1}$, Victor Marudut Mulia Siregar ${ }^{2}$, Sarida Sirait ${ }^{3}$, Angellyna Surya Winata ${ }^{4}$ \\ ${ }^{1,4}$ Prodi Manajemen, Sekolah Tinggi Akuntansi dan Manajemen Indonesia (STAMI) \\ ${ }^{2}$ Prodi Teknik Komputer, Politeknik Bisnis Indonesia (PBI) \\ ${ }^{3}$ Komputerisasi Akuntansi, Politeknik Bisnis Indonesia (PBI) \\ ${ }^{1}$ kisno.shinoda@stami.ac.id \\ 2victor.siregar2@gmail.com \\ ${ }^{3}$ saridasrt@gmail.com \\ 4angellynachen12@gmail.com
}

\begin{abstract}
ABSTRAK
Pandemi Covid-19 menimbulkan berbagai problematika dalam proses pembelajaran di berbagai belahan dunia termasuk Indonesia. Pembelajaran yang semula dilakukan secara tatap muka, berubah total menjadi Pembelajaran Jarak Jauh (PJJ) dan Belajar Dari Rumah (BDR). Kaget teknologi dan motivasi dalam pembelajaran menjadi menurun, tidak hanya pada peserta didik namun juga kepada guru. Hal ini juga terjadi di Sekolah Dasar Negeri yang berada di Kecamatan Patumbak, Kabupaten Deli Serdang, Sumatera Utara. Dengan mengetahui permasalahan ini, tim memberikan solusi dengan mengadakan diseminasi Literacycloud untuk guru dan orangtua di sekolah dasar negeri. Metode yang diselenggarakan selama kegiatan ini adalah menyelenggarakan pre-tes, memberikan pengimbasan secara daring melalui webinar, memberikan pengimbasan secara luring, supervisi secara daring menyelenggarakan pos-tes dan membagikan kuesioner kepuasan peserta pelatihan. Hasil dari kegiatan pengabdian ini adalah seluruh peserta kegiatan baik guru maupun orangtua peserta didik mengalami peningkatan pengetahuan secara signifikan mengenai strategi membaca yang menyenangkan; Selain itu terjadi peningkatan kepemilikan akun pelantar Literacycloud. Selanjutnya, beberapa guru telah memahami dengan sangat baik penggunaan Literacycloud yang dibuktikan dengan praktik baik yang telah dilakukan dan sebanyak $92 \%$ peserta menyatakan bahawa mereka puas dengan diseminasi dan seluruh rangkaian kegiatan yang telah dilakukan oleh tim.
\end{abstract}

Kata kunci: literacycloud, diseminasi, Sekolah Dasar, guru dan orangtua

\section{ABSTRACT}

The Covid-19 pandemic has caused various problems in the learning process worldwide including Indonesia. The learning processes, which was used to face-to-face, has completely changed to Distance Learning and Learning from Home. Technology shock and motivation to perform learning decreased not only for students but also for teachers. This phenomenon also occurred in Public Elementary Schools in Patumbak District, Deli Serdang Regency, North Sumatra. Having known this issue, the team provided a solution by carrying out a Literacycloud dissemination for teachers and parents in two public elementary schools. The methods carried out during this activity were conducting pre-tests, providing online dissemination through webinars, providing offline dissemination, carrying out online supervision, conducting post-tests and distributing questionnaires on participant satisfaction. The results of this community service were that all participants experienced a significant increase in knowledge about fun reading strategies. In addition, there was an increase in the ownership of the Literacycloud account. Furthermore, some teachers have understood the use of Literacycloud properly as evidenced by the best practices that have been carried out. Finally, as many as $92 \%$ of participants stated that they were satisfied with the dissemination and the entire series of activities carried out by the team.

Keywords: literacycloud, dissemination, primary school, teachers and parents 


\section{PENDAHULUAN}

Masa pandemi Covid-19 yang telah berlangsung selama kurang lebih 10 bulan menimbulkan berbagai problematika di dalam proses pembelajaran di berbagai belahan dunia, termasuk di Indonesia. Sebanyak 420 juta peserta didik dari berbagai negara di dunia tidak bisa melakukan proses pembelajaran secara langsung di sekolah karena serangan virus yang berbahaya ini memaksa sekolah untuk tutup dan melaksanakan proses pembelajaran dari rumah (Setyorini, 2020).

Tidak hanya pembatasan mode pertemuan yang sebelum masa pandemi dilakukan secara tatap muka, namun proses pembelajaran menuntut waktu yang lebih singkat dan diselenggarakan melalui peramban maupun aplikasi teknologi secara dalam jaringan (daring). Hal ini memicu permasalahan yang lain yakni fasilitas serta infrastruktur yang diperlukan dalam melaksanakan pembelajaran secara daring dan rendahnya kemampuan dalam menggunakan serta memanfaatkan teknologi baik bagi pendidik maupun peserta didik (Yusron, Wijayanti, \& Novitasari, 2020). Keadan ini terjadi hampir di seluruh tingkat satuan pendidikan di Indonesia termasuk sekolah dasar.

Sekolah dasar (SD) dan tingkat Pendidikan Anak Usia Dini (PAUD) memiliki permasalahan yang lebih pelik selama proses pembelajaran daring. Sebagian besar peserta didik PAUD dan SD merupakan peserta didik yang masih berada pada fase sensorik-motorik dan fase kognisi di mana proses penalaran mereka belum maksimal selayaknya remaja atau orang dewasa sehingga membutuhkan tuntunan langsung dari guru.

Berbagai tindakan telah diupayakan untuk mengatasi permasalahan ini di antaranya dengan pendampingan pengemasan bahan belajar literasi dalam format digital (Hamid, Ili, \& Kansil, 2020), peningkatan kompetensi guru dalam mengevaluasi pembelajaran daring menggunakan aplikasi berbasis tes dan penugasan online (Pagarra, Bundu, Irfan, Hartoto, \& Raihan, 2020), peningkatan kompetensi guru sekolah dasar dalam mengembangkan bahan ajar digital (Faisal, Hotimah, Nurhaedah, Nurfaizah, \& Khaerunnisa, 2020), pemanfaatan media Big Book untuk meningkatkan kemampuan membaca permulaan peserta didik sekolah dasar (Djaga, Riangtati, \& Usman, 2020), dan inovasi pembelajaran bagi guru sekolah dasar dalam mendesain video pembelajaran (Leasa, Syam, Sayyadi, \& Batlolona, 2020) . Seluruh kegiatan pengabdian kepada masyarakat tersebut mendukung proses pembelajaran jarak jauh (PJJ) yang diselenggarakan sebelum dan selama masa pandemi.

Meskipun demikian, perbedaan situasi geografis dan konteks pada satuan pendidikan membutuhkan strategi yang berbeda pula. Strategi yang dilakukan untuk mengatasi masalah ini selaiknya berhubungan dengan literasi dan program pemerintah lainnya. Terkait dengan kebijakan pemerintah mengenai Asesmen Nasional (AN) yang direncanakan digelar pada bulan September hingga Oktober 2021, literasi membaca dan literasi numerasi menjadi kompetensi dasar yang akan diujikan kepada peserta didik. Literasi membaca merupakan fokus utama pada kegiatan pengabdian kepada masyarakat ini.

Sekolah Dasar Negeri di Kecamatan Patumbak, Kabupaten Deli Serdang yang menjadi mitra memiliki masalah dalam meningkatkan motivasi peserta didik dalam membaca. Kemampuan membaca akan menjadi salah satu tolok ukur yang diujikan dalam pelaksanaan Asesmen Nasional sehingga satuan pendidikan tersebut menginginkan bagaimana peserta didik mau membaca sekalipun kegiatannya dilaksanakan secara daring maupun belajar dari rumah. Oleh karena itu, tim memutuskan untuk membantu sekolah tersebut memecahkan masalah yang mereka hadapi dengan menyelenggarakan pendempaingan penggunaan Literacycloud melalui strategi membaca yang menyenangkan.

Literacycloud merupakan sebuah pelantar daring oleh Room to Read yang bisa diakses dimanapun oleh siapapun untuk menemukan sumber-sumber yang membantu penggunanya untuk: (1) Mengembangkan buku cerita yang berkualitas untuk dibaca semua anak; (2) Mengembangkan lingkungan positif yang memotivasi anak untuk membaca; (3) Menggunakan buku-buku dan video-video untuk menumbuhkan kesenangan membaca untuk semua anak dan (4) Bekerjasama dengan orang tua dan yang lainnya untuk meningkatkan kemampuan membaca bagi semua anak.

$\begin{array}{cccc} & \text { Literacycloud } & \text { yang dapat diakses } \\ \text { secara } & \text { gratis } & \text { melalui } & \text { laman }\end{array}$
https://literacycloud.org/ dipilih menjadi media daring untuk membantu sekolah karena bukubuku yang tersedia di dalam pelantar daring tersebut memenuhi kriteria buku yang baik untuk anak-anak yakni: (1) Cerita sesuai dengan budaya dan usia anak-anak; (2) Anak-anak familiar dengan karakternya; (3) Terdapat katakata dan aksi yang menarik; (4) Ilustrasi yang 
menarik yang dapat membantu menceritakan cerita dan (5) Ada berbagai genre dan tema.

Tujuan kegiatan pengabdian kepada masyarakat ini tidak hanya untuk memberikan pemecahan masalah bagi sekolah melalui pelatihan penggunaan pelantar daring bagi guru-guru, namun di sisi lain untuk mengenalkan dan menerapkan teknologi yang sesuai dengan kebutuhan pengguna. Selain itu, kegiatan ini juga bertujuan untuk meningkatkan kesadaran akan pelibatan dan pendampingan orangtua kepada anak-anak mereka selama proses belajar dari rumah (BDR). Kontrol dan pendampingan orangtua semakin diperlukan untuk meningkatkan motivasi belajar anak (Siahaan, 2020) sehingga kegiatan pengabdian ini diharapkan memberikan manfaat kepada tiga sasaran sekaligus yakni sekolah, peserta didik, dan orangtua peserta didik.

METODE KEGIATAN
Pengimbasan dan pelatihan penggunaan pelantar Literacycloud bagi para guru dan orangtua dilakukan di UPT SPF SDN 101791 dan SDN 101793 yang berada di Kecamatan Patumbak, Kabupaten Deli Serdang, Sumatera Utara. Sebanyak 21 orang guru dan 5 orangtua peserta didik menjadi sasaran diseminasi Literacycloud selama bulan Oktober 2020.

Metode yang diselenggarakan selama kegiatan ini adalah: (1) Menyelenggarakan pretes; (2) Memberikan pengimbasan secara daring melalui webinar; (3) Memberikan pengimbasan secara luring; (4) Supervisi secara daring; dan (5) Menyelenggarakan pos-tes dan membagikan kuesioner kepuasan peserta diseminasi.

Pre-tes dilakukan untuk mengetahui sejauh mana pengetahuan guru maupun orangtua peserta didik dalam memahami strategi membaca yang menyenangkan. Pengimbasan secara daring dilakukan melalui webinar mengenai strategi membaca yang menyenangkan melalui pelantar Zoom Meeting. Kedua tahap awal ini dilakukan secara bersamaan secara daring.

Pengimbasan secara langsung dilakukan dengan cara mengirimkan surat pengantar dari Putera Sampoerna FoundationSchool Development Outreach (PSF-SDO) yang bekerjasama dengan Room to Read. Tim baru bisa mengunjungi sekolah atas izin kepala sekolah dengan menerapkan protokol kesehatan. Pada fase ini, para guru dan orangtua peserta didik diberikan bagaimana cara menggunakan pelantar Literacycloud. Setelah para guru dan orangtua diberikan pendampingan, mereka diminta untuk mempraktikkan apa yang telah mereka ketahui kepada peserta didik secara daring atau anakanak di lingkungan rumah mereka dalam jangka waktu 2 minggu. Hasil dari praktik yang mereka lakukan diunggah melalui akun YouTube sekolah atau pribadi.

Fase terakhir yakni pos-tes dilakukan secara daring dengan tujuan untuk mengetahui apakah ada perbedaan pengetahuan para guru dan orangtua peserta didik setelah menerima pelatihan dan pendampingan yang dilakukan oleh tim. Pada fase ini juga kuesioner disebarkan untuk mengetahui sejauh mana efektifitas dan signifikansi dari kegiatan pengabdian kepada masyarakat ini. Selain itu, fase ini juga berguna untuk dijadikan referensi untuk mengevaluasi seluruh kegiatan yang sudah dilaksanakan sehingga dapat memberi rujukan bagi kegiatan lainnya di masa mendatang.

\section{HASIL \& PEMBAHASAN}

Kegiatan yang diselenggarakan pada bulan Oktober 2020 ini dimulai dengan penjajakan terhadap masalah dan kebutuhan satuan pendidikan. Setelah fase tersebut selesai dilaksanakan, ternyata guru dan orangtua tidak memiliki solusi tertentu dalam memotivasi peserta didik dalam belajar, khususnya minat membaca. Dalam masa pandemi seperti saat kegiatan ini dilaksanakan, proses pembelajaran sealu dilakukan secara daring menggunakan gawai atau perangkat-perangkat pendukung lainnya. Tidak jarang juga ditemukan bahawa orangtua maupun guru mengeluh karena peserta didik cenderung tidak belajar karena terdistraksi dengan permainan atau game atau sosial media.

Untuk mengatasi permasalahan tersebut, peneliti menghadirkan sebuah solusi melalui diseminasi secara daring melalui pelantar pertemuan Zoom sebanyak satu kali. Pada tahap ini ada dua fase yang dilakukan sekaligus yakni mengadakan pre-tes untuk mengetahui tingkat pengetahuan para guru atau orangtua mengenai literasi membaca sekaligus webinar mengenai strategi membaca yang menyenangkan. 


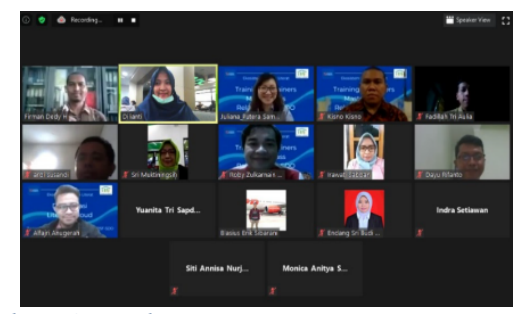

Gambar 1. Webinar Diseminasi Literacycloud

Kegiatan ini diikuti oleh seluruh guru dari UPT SPF SDN 101791 dan SDN 101793 Kecamatan Patumbak dan hasil pre-tes para guru dan orangtua peserta didik menunjukkan skor rata-rata 57 . Sebagian besar dari guru dan orangtua peserta didik masih belum mampu membedakan membaca dengan literasi. Mereka cenderung mengidentikkan kedua istilah tersebut, dengan artian bawah literasi adalah kegiatan membaca, menulis atau sebaliknya. Selain itu, para guru dan orangtua peserta didik cenderung keliru dalam mengklasifikasikan aktivitas mana yang termasuk keterampilan membaca dan mana yang merupakan kebiasaan membaca.

Para guru dan orangtua murid memiliki pengetahuan yang rendah mengenai jenis buku bacaan dan buku bacaan tambahan. Selanjutnya mereka juga tidak mengenal buku bacaan digital yang dapat mendukung proses pembelajaran maupun literasi membaca.

Dengan berlandaskan temuan pada fase awal kegiatan ini, tim memutuskan untuk mengunjungi sekolah sekaligus mengadakan diseminasi secara tatap muka langsung kepada para guru dan orangtua peserta didik. Kegiatan ini berlangsung selama 5 jam berturut-turut dan dihadiri oleh 21 guru dan 5 orangtua.
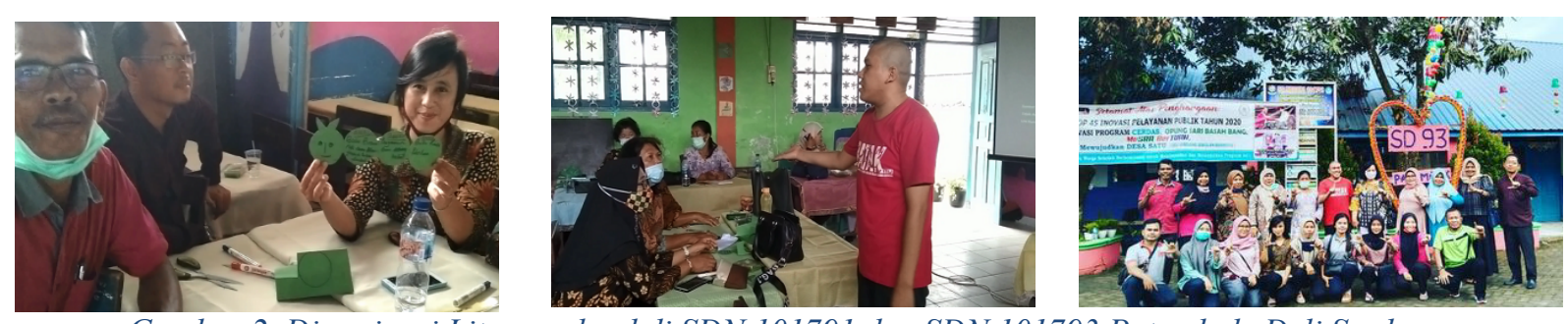

Gambar 2. Diseminasi Literacycloud di SDN 101791 dan SDN 101793 Patumbak, Deli Serdang

Fase diseminasi ini diawali dengan memberikan materi mengenai keterkaitan antara literasi dan membaca. Literasi adalah kemampuan membaca, memahami, dan menganalisis informasi atau bacaan. Dengan kata lain, jika seseorang mampu membaca namun dia tidak memahami apa yang dibaca, maka sesungguhnya dia tidak membaca. Hal ini sejalan dengan penelitian yang mengkaji tentang "membaca fungsional" atau functional reading yakni suatu proses membaca di mana pembaca tidak hanya mampu menyerap gagasan dari sebuah teks, namun juga mampu memahami dan mengkaitkan manfaat dari yang dibaca dan mewujudkannya menjadi tindakantindakan yang positif dalam kehidupan seharihari (Kisno, 2020).

Literasi membaca erat kaitannya dengan kemampuan membaca dan kebiasaan membaca. Kedua kompetensi dasar ini merupakan irisan dari kemampuan untuk menguraikan, memahami, serta menikmati bahan bacaan. Kegiatan-kegiatan yang termasuk dalam kemampuan membaca anak antara lain adalah: (1) Melafalkan kata dengan benar; (2) Mengidentifikasi kata-kata yang mempunyai bunyi yang sama; dan (3) Membacakan kalimat dengan benar kepada guru. Sedangkan kebiasan membaca anak dapat dilihat dari aktivitas seperti: (1) Memilih buku, membaca cerita dengan berpasang-pasangan; (2) Memilih buku sesuai dengan jenjangnya dimana kebanyakan kata-katanya sudah dikenal; dan (3) Mendengarkan guru yang membacakan cerita dengan ekspresi yang menarik. Kegiatan terakhir ini menuntut kemampuan guru untuk menciptakan suasana pembelajaran yang menyenangkan sehingga apa yang disampaikan oleh guru akan lebih bermakna bagi peserta didik (Jumardi, Andi, \& Siswanto, 2020).

Dengan adanya diseminasi secara tatap muka ini, para guru dan orangtua peserta didik lebih memahami hakikat dari literasi itu sendiri. Selain itu, diseminasi ini berguna untuk mendukung Asesmen Nasional yang salah satu kompetensi dasarnya adalah literasi membaca. Diseminasi ini juga menimbulkan kesadaran bahwa apa yang selama ini menjadi persepsi para guru dan orangtua peserta didik adalah keliru dan harus segera diperbaiki apalagi mereka berada dalam lingkungan pendidikan 
sekolah dasar. Kesadaran ini diperkuat oleh penelitian yang menyatakan bahwa prioritas utama membangun sebuah bangsa adalah dengan membangun masyarakat yang literat. Tingkat literasi yang baik berkorelasi dengan kemajuan suatu bangsa (Shara, Andriani, Ningsih, \& Kisno, 2020).

Pada fase diseminasi ini, para guru dan orangtua peserta didik diberikan 3 buah ragam membaca yang menyenangkan yakni teknik membaca senyap berkesinambungan (Uninterrupted Sustained Silent Reading) di mana pembaca biasanya memilih sumber bacaan yang mereka suka, membaca tanpa suara dalam waktu tertentu tanpa interupsi, tidak ada kewajiban untuk menyelesaikan seluruh isi buku, dan tidak harus menjawab tes dari sumber bacaan yang dibaca (Gardiner, 2001). Teknik kedua adalah Piramida Membaca (Story Pyramid) yang merupakan sebuah teknik di mana pembaca meringkas apa yang telah dibaca menjadi tiga bagian yakni bagian awal, tengah, dan akhir. Ringkasan tersebut kemudian dituliskan kembali dalam kalimat yang singkat ke dalam sebuah piramida tiga sisi. Masingmasing ringkasan mencerminkan bagian yang sangat penting dan mudah diingat pembaca. Teknik piramida membaca ini terbukti efektif dalam pengajaran membaca pada peserta didik (Rivani, 2018).

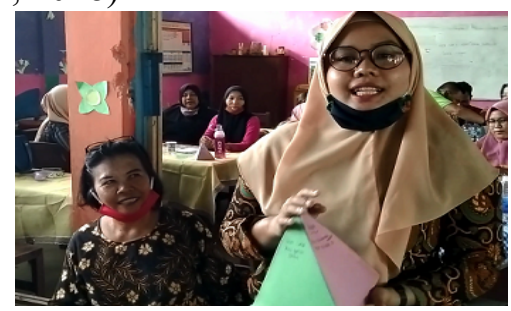

Gambar 3. Praktik Piramida Membaca

Teknik yang ketiga adalah dengan teknik BookTalk yakni membaca nyaring dengan menggunakan sumber bacaan tambahan yang berasal dari Literacycloud. Langkahlangkah yang dilakukan pada teknik ini adalah memberikan stimulan kepada pendengar, membacakan cerita dengan menggunakan bahan bacaan, memberikan pertanyaan-

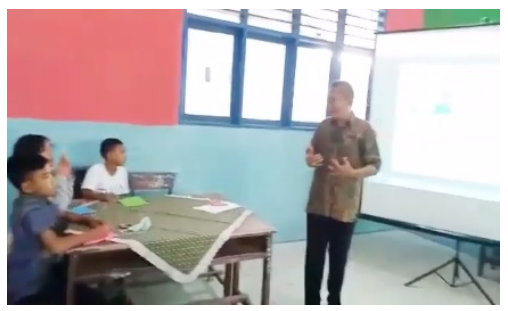

Gambar 4. Praktik BookTalk pertanyan yang bersifat prediktif kepada penyimak, dan menutup cerita dengan memberikan pertanyaan yang berasal dari bagian tertentu dari cerita.

Seluruh rangkaian kegiatan tersebut menjadi praktik yang harus dilakukan oleh masing-masing guru atau orangtua baik secara individu atau secara berkelompok. Praktik baik ini dilaksanakan selama dua minggu sejak diseminasi dilakukan di sekolah.

Hasil dari kegiatan ini adalah ada sejumlah guru yang mempraktikkan BookTalk ini dan hasilnya diunggah ke dalam kanal Youtube milik sekolah dengan laman akses https://s.id/xu4MJ,https://s.id/xu4Qc, https://s.id/xu4SS,https://s.id/xu4Uf, https://s.id/xu4-8. Untuk menutup kegiatan pengabdian ini, tim memberikan pos-tes dan kuesioner mengenai tingkat kepuasan serta kepemilikan akun Literacycloud kepada seluruh peserta. Hasil pre-tes yang diperoleh terdapat pada Gambar 5.

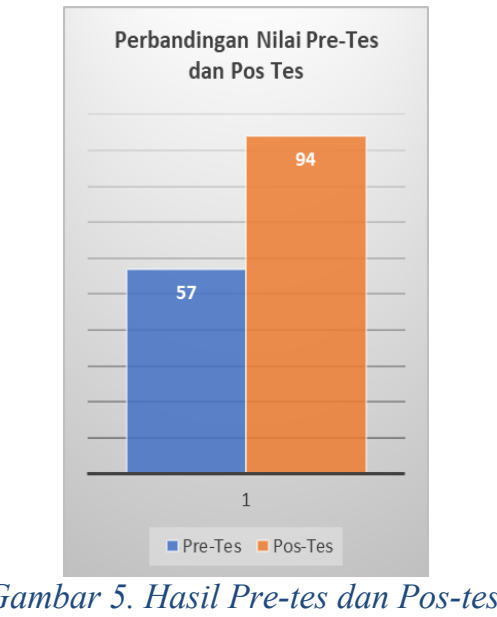

Hasil pre-tes dan pos-tes dari seluruh peserta kegiatan dapat dilihat pada Gambar 5. Gambar tersebut menunjukkan adanya peningkatan hasil yang signifikan sebesar 37 poin. Peningkatan ini terjadi setelah para guru dan orangtua peserta didik memperoleh diseminasi dalam bentuk webinar dan kunjungan langsung ke sekolah. Selain itu, praktik nyata selama diseminasi secara tatap muka turut membantu peningkatan pengetahuan mereka mengenai strategi membaca yang menyenangkan. Dengan meningkatnya pengetahuan para guru dan orangtua, beberapa dampak negatif seperti keterbatasan pengetahuan akan penggunaan teknologi baik oleh guru maupun peserta didik, kerugian pada sistem penilaian (Aji, 2020) dapat teratasi dengan penyesuaian mode 
pembelajaran melalui ragam membaca yang menyenangkan.

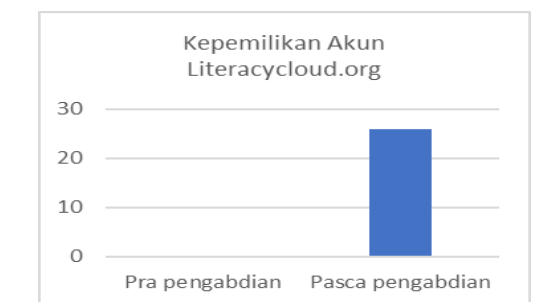

Gambar 6. Jumlah Akun Literacycloud

Selama diseminasi daring maupun luring, peserta diminta untuk memiliki akun pada https://literacycloud.org/ dengan cara registrasi langsung ke pelantar tersebut. Pada akhir kegiatan, seluruh guru dan orangtua yang terlibat sebagai sasaran kegiatan pengabdian ini sudah memiliki akun penyedia sumber bacaaan digital yang memiliki fitur simpan secara luring seperti yang ditunjukkan pada Gambar 6 . Peningkatan kepemilikan akun ini akan turut membantu penyelenggaraan PJJ dan BDR selama masa pandemi dengan cara menggabungkan dua mode yakni mode konvensional dan mode daring sehingga baik guru dan peserta didik sama-sama bisa mengkonstruksi pengetahuannya secara aktif dan nyaman (Dewi, 2020).

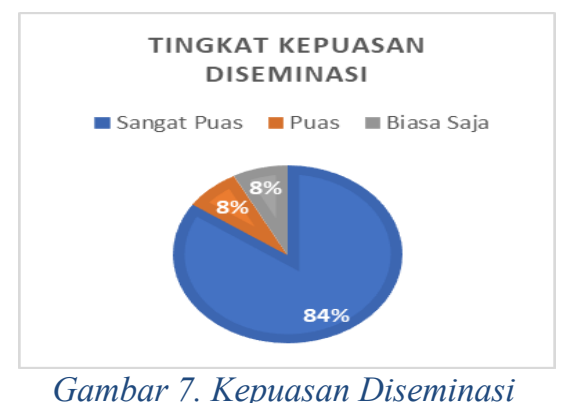

Tingkat kepuasan diseminasi Literacycloud dapat dilihat pada Gambar 7. Hampir 92\% responden menyatakan puas terhadap apa yang sudah dilakukan oleh tim. Kepuasan mereka terleihat dari semangat saat mengikuti diseminasi secara daring dan luring, tingkat kepatuhan dalam mengerjakan praktik baik dan kemauan mengerjakan pre-tes dan postes. Dalam kegiatan webinar, diseminasi luring serta pengerjaan pre-tes dan pos-tes tidak ada peserta yang tidak hadir. Hal ini mendukung bahwa motivasi mereka untuk berpartisipasi dalam kegiatan ini sangat tinggi.

\section{KESIMPULAN \& SARAN}

Setelah seluruh rangkaian kegiatan pengabdian kepada masyarakat ini dilakukan, kesimpulan yang dapat dideskripsikan adalah sebagai berikut: (1) Seluruh peserta kegiatan baik guru maupun orangtua peserta didik mengalami peningkatan pengetahuan mengenai strategi membaca yang menyenangkan; (2) Baik para guru maupun orangtua sudah memiliki akun pelantar Literacycloud. (3) Beberapa guru telah memahami dengan sangat baik penggunaan Literacycloud yang dibuktikan dengan praktik baik yang telah dilakukan dan (4) Mayoritas peserta menyatakan bahawa mereka puas dengan diseminasi dan seluruh rangkaian kegiatan yang telah dilakukan oleh tim.

Sebagai rekomendasi dari hasil kegiatan pengabdian masyarakat ini, tim memberikan saran agar seluruh guru yang telah hadir dalam diseminasi secara daring dan luring mau mempraktikkan hal-hal yang sudah diketahui sehingga Gerakan Literasi Nasional yang sudah digagas dengan baik oleh pemerintah dapat berjalan dengan maksimal. Dengan semakin maksimalnya gerakan literasi yang diselenggarakan di berbagai daerah di seluruh Indonesia, hal ini turut membantu mensukseskan Asesmen Nasional.

\section{DAFTAR PUSTAKA}

Aji, R. H. (2020). Dampak Covid-19 pada Pendidikan di Indonesia: Sekolah, Keterampilan, dan Proses Pembelajaran. SALAM; Jurnal Sosial \& Budaya Syar-i, 7(5), 395-402. doi:10.15408/sjsbs.v7i5.15314

Dewi, W. A. (2020). Dampak Covid-19 terhadap Implementasi Pembelajaran Daring di Sekolah Dasar. Edukatif : Jurnal Ilmu Pendidikan, 2(1), 55-61. doi:10.31004/edukatif.v2i1.89

Djaga, S., Riangtati, A. D., \& Usman, H. (2020). Pemanfaatan Media Big Book untuk Meningkatkan Kemampuan Membaca Permulaan pada Siswa Kelas II SD Negeri Gunung Sari II Makassar. Jurnal Publikasi Pendidikan, 1(1), 6572 .

doi:

10.26858/publikan.v10i1.12829

Faisal, M., Hotimah, Nurhaedah, Nurfaizah, \& Khaerunnisa, K. (2020). Peningkatan Kompetensi Guru Sekolah Dasar dalam Mengembangkan Bahan Ajar Digital di Kabupaten Gowa. Jurnal Publikasi Pendidikan, 10(3), 266-270. doi:https://doi.org/10.26858/publikan. v10i3.16187 
Gardiner, S. (2001). Ten Minutes a Day for Silent Reading. Educational Leadership, 59(2), 32-35.

Hamid, R., Ili, L., \& Kansil, Y. E. (2020). Pendampingan Pengemasan Bahan Belajar Literasi dalam Format Digital Bagi Guru Sekolah Dasar di Kota Kendari . Jurnal Publikasi Pendidikan 10(3), 197-201. doi:https://doi.org/10.26858/publikan. v10i3.14391

Jumardi, Andi, \& Siswanto, R. D. (2020). Workhsop Peningkatan Profesionalisme Guru SD Melalui Kompetensi Membuat Media Pembelajaran IPS . Jurnal Publikasi Pendidikan , 10(2), 119-124. doi:10.26858/publikan.v10i2.11372

Kisno. (2020). Pomodoro Technique for Improving Students' Reading Ability during Covid-19 Pandemic. Jurnal Education and Development, 8(3), 1-6. doi:https://doi.org/10.37081/ed.v8i3.1 753

Leasa, M., Syam, F. A., Sayyadi, M., \& Batlolona, J. R. (2020). Inovasi Pembelajaran Bagi Guru Sekolah Dasar Dalam Mendesain Video Pembelajaran. Jurnal Publikasi Pendidikan , 10(1), 80-87. doi:https://doi.org/10.26858/publikan. v10i1.10454

Pagarra, H., Bundu, P., Irfan, M., Hartoto, \& Raihan, S. (2020). Peningkatan Kompetensi Guru Dalam Mengevaluasi Pembelajaran Daring Menggunakan Aplikasi Berbasis Tes Dan Penugasan Online. Jurnal Publikasi Pendidikan, 10(3), 260-265. doi:https://doi.org/10.26858/publikan. v10i3.16069

Rivani, T. (2018). The Effectiveness of Story Pyramid Strategy to Teach Reading at Tenth Grade of SMK Negeri Sragen in Academic Year 2018/2019. . Surakarta: English Education Study Program, Islamic Education and Teacher Training Faculty. .

Setyorini, I. (2020). Pandemi Covid-19 Dan Online Learning : Apakah Berpengaruh Terhadap Proses Pembelajaran Pada Kurukulum 13? Journal of Industrial Engineering \& Management Research (JIEMAR) , 1(1), 95-102. doi: https://doi.org/10.7777/jiemar.v1i

Shara, A. M., Andriani, D., Ningsih, A. W., \& Kisno. (2020). Correlating Reading
Literacy and Writing Literacy in Junior High School Pematangsiantar. Journal of English Education, 5(2), 72-85. doi:https://doi.org/10.31327/jee.v5i2.1 249

Siahaan, M. (2020). Dampak Pandemi Covid19 Terhadap Dunia Pendidikan. Jurnal Kajian Ilmiah (JKI) , 1, 1-3.

Yusron, R. M., Wijayanti, R., \& Novitasari, A. T. (2020). Pelatihan Pembuatan Google Formbagi Guru SD Sebagai Media Evaluasi Pembelajaran Jarak Jauh (PJJ) Masa Pandemi. Jurnal Publikasi Pendidikan, 10(3), 182-188. doi:https://doi.org/10.26858/publikan. v10i3.15055 